\title{
Preface—special issue in memory of Frank J. Stevenson
}

\author{
Heike Knicker ${ }^{1}$ - Fernando L. Rosario-Ortiz ${ }^{2}$. Claudio Zaccone ${ }^{3}$ \\ Received: 13 February 2018 / Accepted: 14 February 2018 / Published online: 22 February 2018 \\ (C) Springer-Verlag GmbH Germany, part of Springer Nature 2018
}

Natural organic matter (NOM) comprises a complex mixture of thousands of organic compounds found in water, soils, and sediments that was naturally formed from residues of plants, microorganisms, and animal matter at various stages of the decaying process. It is ubiquitous and plays an important role for the functioning of ecosystems. In soils it appears as soil organic matter (SOM) and in surface water mostly as dissolved (DOM) or particulate organic matter (POM). However, it occurs also in fossil and recent sediments as well as in composts, sewage sludge, or organic waste. Its chemical composition and physical properties can vary largely and depend on the quality of the substrate, the environmental conditions in which it was formed and the time and intensity of its humification. According to the International Humic Substance Society (IHSS), humification describes the chemical and biochemical processes included in the degradation and transformation of plant and microbial residues into the so called humic substances (HS) (IHSS 2017). NOM is involved in many processes in soils and natural waters, e.g., weathering, plant nutrition, $\mathrm{pH}$ buffering, major and trace metal mobility and toxicity, bioavailability, transport of organic chemicals and inorganic compounds, formation of disinfection by-products during water treatment, and heterotrophic production in blackwater ecosystems. Bearing this in mind, a better understanding of the character and function of NOM and HS are of broad interest and have received attention from scientists in a wide variety of discipline.

Heike Knicker

knicker@irnase.csic.es

1 Departamento: Biogeoquímica, Ecología Vegetal y Microbiana, Instituto de Recursos Naturales y Agrobiología de Sevilla (IRNAS-CSIC), Avda. Reina Mercedes 10, E-41012 Sevilla, Spain

2 Department of Civil, Environmental and Architectural Engineering, 428 UCB, University of Colorado at Boulder, Boulder, CO 80309, USA

3 Department of the Sciences of Agriculture, Food and Environment, University of Foggia, Via Napoli 25, 71122 Foggia, Italy
Frank J. Stevenson (1922-2015) was one of the scientists who dedicated their professional life to increase our understanding of the properties and functions of NOM. He can be certainly considered as a pioneer of NOM and HS research by exploring innovative approaches to the study of both bulk SOM and humus chemistry. For more than thirty years, he was among the most influential in pushing forward the frontiers and guiding the directions in these research areas, which encouraged the IHSS to dedicate this Special Issue to his memory.

Elected in 1988 at the 4th Meeting of the IHSS in Matalascañas (Spain), F.J. Stevenson was the third honorary member of the IHSS, joining Prof. W. Flaig (1984) and Dr. M. Schnitzer (1986) (IHSS 1989).

By successfully combining physical, chemical, and biochemical approaches, he paved not only the way to a better understanding of biogeochemical processes in soils but also of interactions between SOM and clays, as well as heavy metal binding by HS. He is author of numerous book chapters, original papers published regularly in top quality scientific journals, and the first and second edition of a fundamental scientific book "Humus Chemistry: Genesis, Composition, Reactions" (Stevenson 1982, 1994). The latter have been widely used as "must read" texts in advanced level courses and have guided and inspired generations of soil chemists. They certainly have been seen as a fundamental for the development of modern analytical approaches for the study of SOM and HS, as well as for the understanding of their composition and function. A more detailed description of Frank Stevenson's accomplishments is subject of the first contribution of this special issue "An appreciation of the contribution of Frank Stevenson to the advancement of studies of soil organic matter and humic substances" by Hayes and Swift (2018).

However, investigation with and about NOM is still a challenging task and has not lost its importance. As can be seen by the 17 contributions from various research areas to the present special issue, the study of NOM still has broad relevance for a better understanding of environmental processes. 
The latter was also the intention of Bianchini and da Cunha-Santino (2018) who studied the contribution of HS as a sink and source of carbon $(\mathrm{C})$ in tropical floodplain lagoons by experiments in which humic (HA) and fulvic (FA) acids isolated from decomposition of Oxycaryum cubense were degraded both under oxic and unoxic conditions. Although the mineralization pathway yields varied according to the type of resource and oxygen availability, they observed similar degradation rates, suggesting a similar microbial catabolism efficiency during the decay of HS.

Based on the fact that soil nitrogen $(\mathrm{N})$ is mainly retained as soil organic N, Calazans et al. (2018) determined N contents in the tropical soils under native vegetation in Minas Gerais, Brazil, in order to identify the main factors affecting its sequestration. Their results led to the conclusion that in those soils, the $\mathrm{N}$ content can be adequately predicted based on data obtained after wet-combustion of SOM.

In the third article of the special issue, Assunção et al. (2018) evaluated the role of aquatic macrophytes in the formation and mineralization kinetics of dissolved HS under aerobic and anaerobic conditions. They observed an increase of HA and FA concentrations in water, with differences in formation rate due to the presence or absence of oxygen. Song et al. (2018) used high-resolution mass spectrometry to evaluate the differences of the chemical composition between various fractions of DOM collected from a reservoir. Using absorption and fluorescence spectra in combination with derivative spectroscopy, Yakimenko et al. (2018) compared humic products from various environments, both as bulk materials and their HA fractions. HA-like fractions were isolated from commercially available humates, industrially manufactured from a number of raw source materials, such as brown coal, leonardite, peat, lake sediment, and lignosulphonate. They concluded that these techniques might serve as inexpensive and robust tools to discriminate humic products from various environments.

In a further contribution, Senesi et al. (2018) critically reviewed results obtained by the application of laser-based spectroscopic methods for the evaluation of the humification degree of SOM in whole soils, whereas Almendros et al. (2018) tested dipolar dephasing ${ }^{13} \mathrm{C}$ NMR spectroscopy as a mean to distinguish "inherited" from "pyrogenic" aromatic structures.

Analyzing ashy sediment samples collected from a wildfire impacted area in northern Colorado, USA, Cawley et al. (2018) evaluated the sediment characteristics along the lateral and longitudinal length of a reach of wildfire-impacted river and potential changes in water quality and disinfection byproduct (DBP) formation following a wildfire. The authors observed that burned material accumulated downstream near the river and that was composed of inputs from burned soil and biomass along with the mobilization of unburned terrestrial material. They concluded that DOM leached from sediments following a wildfire may increase aquatic dissolved organic carbon (DOC) concentrations and N-DBP formation.

Many studies in the area of HS research focus on the interactions of those substances with minerals, heavy metals, xenobiotics, and pollutants. In line with this, Kholodov et al. (2018) applied a sessile drop contact angle method to assess the hydrophobic impact of irreversible sorption of HS onto clay mineral surfaces.

The contribution of Chernysheva et al. (2018) evaluated the influence of HS on the fate and behavior in the environment of detonation synthesis nanodiamonds (NDs) that are among the most widely applied nanoparticles due to their low cost of production and broad scope of applications. In particular, the uptake of detonation NDs by wheat seedlings and its toxicity were evaluated in the presence of both HA and FA. This study demonstrated that, when interacting with FA, the ND-FA suspensions possessed smaller zeta potential values, which could indicate their lower colloidal stability, which would result in the greater uptake of NDs by wheat seedlings in the presence of FA than in the presence of HA. In few words, while the introduction of HA in a suspension of NDs reduced the inhibiting effect of the NDs, mitigating activity of FA was not so apparent. Using a multivariate approach, D'Orazio and Miano (2018) demonstrated that excitation-emission matrices spectroscopy (EEMS) represents a useful tool to investigate the molecular and mechanistic aspects of HA adsorbing capacity towards atrazine and paraquat with or without $\mathrm{Cu}^{2+}$ ions. Additional information obtained by PCA analysis show that $\mathrm{Cu}^{2+}$ ions behave like a good antagonist in preventing the formation of ionic bonds between $\mathrm{HA}$ and atrazine, whereas $\mathrm{Cu}$ is not able to affect the prevalent mechanism of HA interaction with paraquat, which is a charge transfer bond.

The investigation by Klein et al. (2018) is based on the observation that HS play important role in the environment by radical scavenging in biogeochemical redox reactions. As such, they are influencing the behavior of pollutants and can preventing damage to cell membranes; this is due to antioxidant properties of HS. Their work aimed to estimate long-term kinetics of those properties of humic and humic-like substances under different $\mathrm{pH}$ in relation to their specific structural features. They revealed that at acidic $\mathrm{pH}$, the antioxidant activity of humic and humic-like substances is mainly related to the presence of $\mathrm{N}$-containing groups rather than phenols. However, for HS, both $\mathrm{N}$-containing compounds and phenolic compounds should be considered.

Application of HS in agriculture has an environmental impact. To optimize the use of HS from vermicomposts in agriculture, García et al. (2018) evaluated the bioactivity of three humic fractions from vermicomposts obtained with different extraction methods. 
Conducting a 5-year field experiment, in which semiarid degraded soils were restored with fresh and composted urban wastes, Lucas et al. (2018) showed that soil amendment enhanced the HS and HA contents. In general, the addition of organic amendments increased the quantity of enzymes immobilized in the humic colloid. Furthermore, the addition of the composted residues favored to a greater extent the immobilization of the abovementioned enzymes, which represent a biological reservoir in the soil.

Fuentes et al. (2018) proposed a new methodology allowing to quantify the content of HS in commercial products (and raw materials) and also to assess the quality of the quantified organic matter. Therefore, HA and FA (-like) fractions have been isolated/purified from several materials and characterized by means of elemental analysis and UV-visible, fluorescence, and infrared spectroscopies. The results were subjected to a discriminant analysis.

In their work, Kulikova et al. (2018) evaluated the release of $\mathrm{N}$ from soil amendments obtained by modifying humic materials from peat and lignite with alkoxyorganosilanes which contain different amine substituents. These amendments released $\mathrm{N}$ in the form of ammonia or nitrate, therefore increasing the fraction of these nutrients in soils.

As Guest Editors, we thank the authors for their contributions to this Special Issue, the referees for their valuable work during the review process, and the IHSS for its support. Special thanks go to Zhihong Xu and Philip N. Owens, Editors-in-Chief of Journal of Soils and Sediments, for their collaboration and for hosting this volume, and Moira Ledger, the Editorial Manager, for her strong support and patience.

\section{References}

Almendros G, Tinoco P, De la Rosa J-M, Knicker H, González-Pérez J-A, González-Vila FJ (2018) Selective effects of forest fires on the structural domains of soil humic acids as shown by dipolar dephasing ${ }^{13} \mathrm{C}$ NMR and graphical-statistical analysis of pyrolysis compounds. J Soils Sediments. https://doi.org/10.1007/s11368-016-1595-y (this issue)

Assunção AWA, Souza BP, da Cunha-Santino MB, Bianchini I (2018) Formation and mineralization kinetics of dissolved humic substances from aquatic macrophytes decomposition. J Soils Sediments. https://doi.org/10.1007/s11368-016-1519-x (this issue)

Bianchini I, da Cunha-Santino MB (2018) Contribution of humic substances as a sink and source of carbon in tropical floodplain lagoons. J Soils Sediments. https://doi.org/10.1007/s11368-016-1638-4 (this issue)

Calazans SOL, Morais VA, Scolforo JRS, Zinn YL, Mello JM, Mancini LT, Silva CA (2018) Soil organic carbon as a key predictor of $\mathrm{N}$ in forest soils of Brazil. J Soils Sediments. https://doi.org/10.1007/ s11368-016-1557-4 (this issue)

Cawley KM, Hohner AK, McKee GA, Borch T, Omur-Ozbek P, Oropeza J, Rosario-Ortiz FL (2018) Characterization and spatial distribution of particulate and soluble carbon and nitrogen from wildfire- impacted sediments. J Soils Sediments. https://doi.org/10.1007/ s11368-016-1604-1 (this issue)

Chernysheva MG, Myasnikov IY, Badun GA, Matorin DN, Gabbasova DT, Konstantinov AI, Korobkov VI, Kulikova NA (2018) Humic substances alter the uptake and toxicity of nanodiamonds in wheat seedlings. J Soils Sediments. https://doi.org/10.1007/s11368-016$1564-5$ (this issue)

D’Orazio V, Miano T (2018) Fluorescence properties of humic acid interaction products with s-triazine and bipyridilium herbicides and their $\mathrm{Cu}$ complexes: a multivariate approach. J Soils Sediments. https://doi.org/10.1007/s11368-016-1611-2 (this issue)

Fuentes M, Baigorri R, González-Gaitano G, García-Mina JM (2018) New methodology to assess the quantity and quality of humic substances in organic materials and commercial products for agriculture. J Soils Sediments. https://doi.org/10.1007/s11368-016-1514-2 (this issue)

García AC, Tavares OCH, Balmori DM, Vd SA, Canellas LP, GarcíaMina JM, Louro Berbara RL (2018) Structure-function relationship of vermicompost humic fractions for use in agriculture. J Soils Sediments. https://doi.org/10.1007/s11368-016-1521-3 (this issue)

Hayes MHB, Swift RS (2018) An appreciation of the contribution of Frank Stevenson to the advancement of studies of soil organic matter and humic substances. J Soils Sediments. https://doi.org/10. 1007/s11368-016-1636-6 (this issue)

IHSS (1989) IHSS communications. IHSS, http://humic-substances.org/ wp-content/uploads/NL_5_1989.pdf

IHSS (2017) What are humic substances, http://humic-substances.org/ what-are-humic-substances-2/

Kholodov VA, Milanovskiy EY, Konstantinov AI, Tyugai ZN, Yaroslavtseva NV, Perminova IV (2018) Irreversible sorption of humic substances causes a decrease in wettability of clay surfaces as measured by a sessile drop contact angle method. J Soils Sediments. https://doi.org/10.1007/s11368-016-1639-3 (this issue)

Klein OI, Kulikova NA, Filimonov IS, Koroleva OV, Konstantinov AI (2018) Long-term kinetics study and quantitative characterization of the antioxidant capacities of humic and humic-like substances. J Soils Sediments. https://doi.org/10.1007/s11368-016-1538-7 (this issue)

Kulikova NA, Filippova OI, Volikov AB, Perminova IV (2018) Slow nitrogen release from humic substances modified with aminoorganosilanes. J Soils Sediments. https://doi.org/10.1007/ s11368-016-1507-1 (this issue)

Lucas EG, Izquierdo CG, Fernández MTH (2018) Changes in humic fraction characteristics and humus-enzyme complexes formation in semiarid degraded soils restored with fresh and composted urban wastes. A 5-year field experiment. J Soils Sediments. https://doi. org/10.1007/s11368-016-1537-8 (this issue)

Senesi GS, Martin-Neto L, Villas-Boas PR, Nicolodelli G, Milori DMBP (2018) Laser-based spectroscopic methods to evaluate the humification degree of soil organic matter in whole soils: a review. J Soils Sediments. https://doi.org/10.1007/s11368-016-1539-6 (this issue)

Song G, Mesfioui R, Dotson A, Westerhoff P, Hatcher P (2018) Comparison of hydrophobic and amphiphilic fractions of dissolved organic matter from a water reservoir by Fourier transform ion cyclotron resonance mass spectrometry. J Soils Sediments. https://doi. org/10.1007/s11368-016-1582-3 (this issue)

Stevenson FJ (1982) Humus chemistry - genesis, composition, reactions. John Wiley \& Sons, Inc., New York

Stevenson FJ (1994) Humus chemistry - genesis, composition, reactions, 2nd edition. John Wiley \& Sons, Inc., New York

Yakimenko O, Khundzhua D, Izosimov A, Yuzhakov V, Patsaeva S (2018) Source indicator of commercial humic products: UV-Vis and fluorescence proxies. J Soils Sediments. https://doi.org/10. 1007/s11368-016-1528-9 (this issue) 